\title{
Gulls-the Grand Birds of the Prairie
}

\author{
BY GORDON W. STEWART, Regina, Sask.
}

To bird lovers there can be few greater thrills than that of watching the wonderful aerial battles staged around farmers' fields by the Franklin and Bonaparte Gulls, for the possession of a mouse, especially a young smooth-haired one. The best bactles are wage $d$ in the mornings when the birds are hungry, and I have often stopped my machine so as to be able to watch the fun.

A mouse will be disturbed by the machine, make a run for other cover, only to be pounced on by a gull. The gull flies aloft with the mouse in its bill and is at once attacked by other gulls. Then is when the wonderful flying of these birds is really something to see -- ducking, diving and dodging with superb skill. Sometimes the mouse is dropped in the fray, but before it reaches the ground another gull will pick it out of the air, only to become the centre of the fight for the unfortunate rodent.

Perhaps by its skill, the gull will out-maneuver its pursuers, or possibly because of some reason known only to gulls, the possessor of the mouse will fly unmolested to another part of the field, where it will kill its prey by squeezing it from end to end in its bill; then turn the mouse and swallow it head first, making several strenuous gulps.

Sometimes it may be unable to get away from its attackers, then with its head far back and wings fluttering to keep itself aloft, the gull will swallow the mouse head first and continue on its hunt for further game, as if nothing had happened.

These gulls follow the farmers' machines in flocks of from less than a dozen to sometimes over a hundred. They will often come within arms reach of the tractor operator; al ways watching for some tid-bit that may be turned up by the machine. When something is sighted, the bird drops to the ground, picks up the prize, then continues its flight watching for further food. After noon they do not seem to be as hungry as they are in the morning and do not display the same fighting spirit. They do not seem tocare for the large coarsehaired mice, though sometimes they will swallow them. These larger mice are prey for the rough-legged hawks which swoop from nowhere, reach with a claw while flying, pick up the mouse and continue their flight to a telephnne pole or just a nearby spot in the field, where they hold the mouse in their claw for a few minutes, then eat it by pulling it to pieces.

Gulls and rough-legged hawks seem to prefer their mice alive. In fact I have never seen either bird pick. up a dead mouse. Crows, on the other rand seem to want their game already killed. I have seen crows standing on fence posts, watching the gulls, and when the latter have killed their mouse, or when the crow believes the mouse to be killed it will attack the gull which soon drops the mouse, to have it picked up by the crow, and carried so far away that I have never been able to see how it disposes of its ill-gotten gain.

A morning spent in the fields where tractors are working and which are being followed by Gulls, would be worth any bird lover's time if he is at all interested in the workings of these grand birds of the prairie.

Billy Matthews of Nipawin saw a Great Gray Owl, near the north-east corner of Fort a la Corne game preserve, January 9.

Flying squirrels are more widely spread throughout the province than is generally realized. The reason for this is that they are nocturnal in habit. Mr. J. Turnquist, who lives near Wallwort, was very surprised, when on February 1st, he caught one in a trap set for rats. He had never seen a Flying squirrel before. 